\title{
WHITMAN, EAKINS, AND THE NAKED TRUTH
}

Whitman-watchers have recently been invited to accept Ed Folsom's suggestion that a suite of photographs of an unclothed bearded old man, taken by Thomas Eakins or one of his assistants in the early 1880 s, may indeed portray the nude Walt Whitman. This controversial proposal was made in the pages of the Walt Whitman Quarterly Review (Spring 1994) and again in Breaking Bounds: Whitman and American Cultural Studies (1996), edited by Betsy Erkkila and Jay Grossman (additional credibility was given to this claim when the publisher reproduced the photograph[s] on the dust jacket). My purpose in this article is to challenge Folsom's thesis and to suggest that it is the result of wishful thinking.

When I first saw the illustration (Figure 1) for Folsom's WWQR article captioned "Thomas Eakins's Multiple Photographs of Whitman Naked?," I thought to myself, this just doesn't look like Whitman. The man's forehead is too high and narrow, and the beard is too long and "square." Seen from behind, much of the model's head is totally bald, whereas representations of Whitman from the same period and later show him with a full mane of hair. And the old man's eyes are deeply sunk, while Whitman's seem close to the surface, hooded rather than recessed. Finally, the face lacks Whitman's slightly puffy, even chubby, look.

I would also say that the historical circumstances surrounding these images indicate that the subject would not be Whitman. The entire "naked series," to which these photographs of the old man belong, Folsom correctly states, offered Eakins "a storehouse of accurate representations of the human body for use in his paintings and art classes." The subjects were principally Eakins's students at the Pennsylvania Academy of the Fine Arts, whom he persuaded to pose sometime in the early 1880 s (probably c. 1883). The majority were young males, but a few females, Eakins himself, a young boy and an old man (the subject of Folsom's claim) were included. Facial masks worn by two of the women suggest that they were paid models, and a few others in the series, both male and female, may have been professionals. In this context, it is most appropriate to assume that the bearded old man was a professional model who, as Dr. Robert Stubbs observes, "was probably . . . hired for posing."2 It is hard to imagine, given Eakins's logical mind and reputation for consistency, that he would have brought Whitman to Philadelphia to pose for what was clearly a pedagogical-photographic exercise.

There is also further evidence that contradicts Folsom's claim - a recently published painting by Eakins student (1879-1882) J. Laurie Wallace of the same old man, seated and entirely nude, dated by Sarah Cash "c. 1880" (Figure 2). The painting is conceived as a figure study, the subject striking a prosaic pose on a model stand. Of course, if one believes the questionable Whitman identity of the series of "old man" photographs, then one could argue that the Wallace painting could be of Whitman too. But the conditions just cited would militate against any such claim.

The arguments presented above should be enough to dissuade readers from believing Folsom's suggestion that the "old man" series portrays the nude Walt Whitman. But in the face of possible lingering doubts, let me deal one by one with Folsom's supporting arguments. 
Folsom agrees that the "naked series" was made between 1882 and 1886, a reasonable assumption. In order for the photograph resembling Whitman to have been taken by Eakins, however, the artist would have had to have met Whitman in or before 1886. This precedes the established date of Eakins's first recorded contact with Whitman in 1887, the result of an introduction made in Camden by the Philadelphia journalist Talcott Williams. Folsom argues that, through his friendship with Williams, Eakins might have encountered Whitman earlier than 1887 , but offers no significant evidence for this claim. There is nothing in Whitman's correspondence, daybooks, or writings about the poet-or in Eakins's letters and biographical accounts-to suggest that Whitman had encountered Eakins before that year. After their meeting, however, Whitman often noted in writing the facts about Eakins's visits to Camden, particularly the artist's efforts to paint his portrait in 1887-88. (From 1888 to 1892 , Horace Traubel chronicled the mutual activities of the two men in With Walt Whitman in Camden.)

Whitman and Eakins, it can be said without doubt, shared a common (though not identical) interest in the nude. For both, the naked human body symbolized a spirit of robust physical health and freedom from prudish conventions. But I think Folsom is incorrect in believing the speculations of poets and critics "about the possibility that there might have been an Eakins painting or photograph of Whitman in the nude." ${ }^{3}$ (I know of no reliable claim of this kind in the world of American art history.) Thinking, as Folsom does, that the "old man" photographs in the "naked series" could fill the bill is to make a postmodern leap of faith. And even when Folsom admits this assumption could be wrong, he presents another postmodern option: that the model "who was a ringer for Whitman" was a kind of substitute "who could serve Eakins as Whitman's body-double for his form studies." 4 As fascinating as this hypothesis might appear in the light of contemporary criticism, it does not ring true. Eakins had a literal mind, resistant to metaphor and poetic subtlety: the idea of the body-double no doubt would have been alien to him.

Rather than accept the bearded old man into the repertory of Whitman images, we need to step back and look long and hard at the historical evidence to the contrary, much of it quite compelling. And we must return with open eyes, once again, to the determining argument presented at the beginning of this article: the old man doesn't look like Whitman.

University of Delaware

WiLliam INNES HoMER

\section{NOTES}

1 “Notes," Walt Whitman Quarterly Review 11 (Spring 1994), 201.

2 Photographer Thomas Eakins (New York: ACA Galleries; Philadelphia and Atlanta: Olympia Galleries, Ltd., 1981), 32.

3 Ed Folsom, "Whitman's Calamus Photographs," in Breaking Bounds: Whitman and American Cultural Studies, ed. Betsy Erkkila and Jay Grossman (New York: Oxford University Press, 1996), 212.

4 Folsom, 212. 

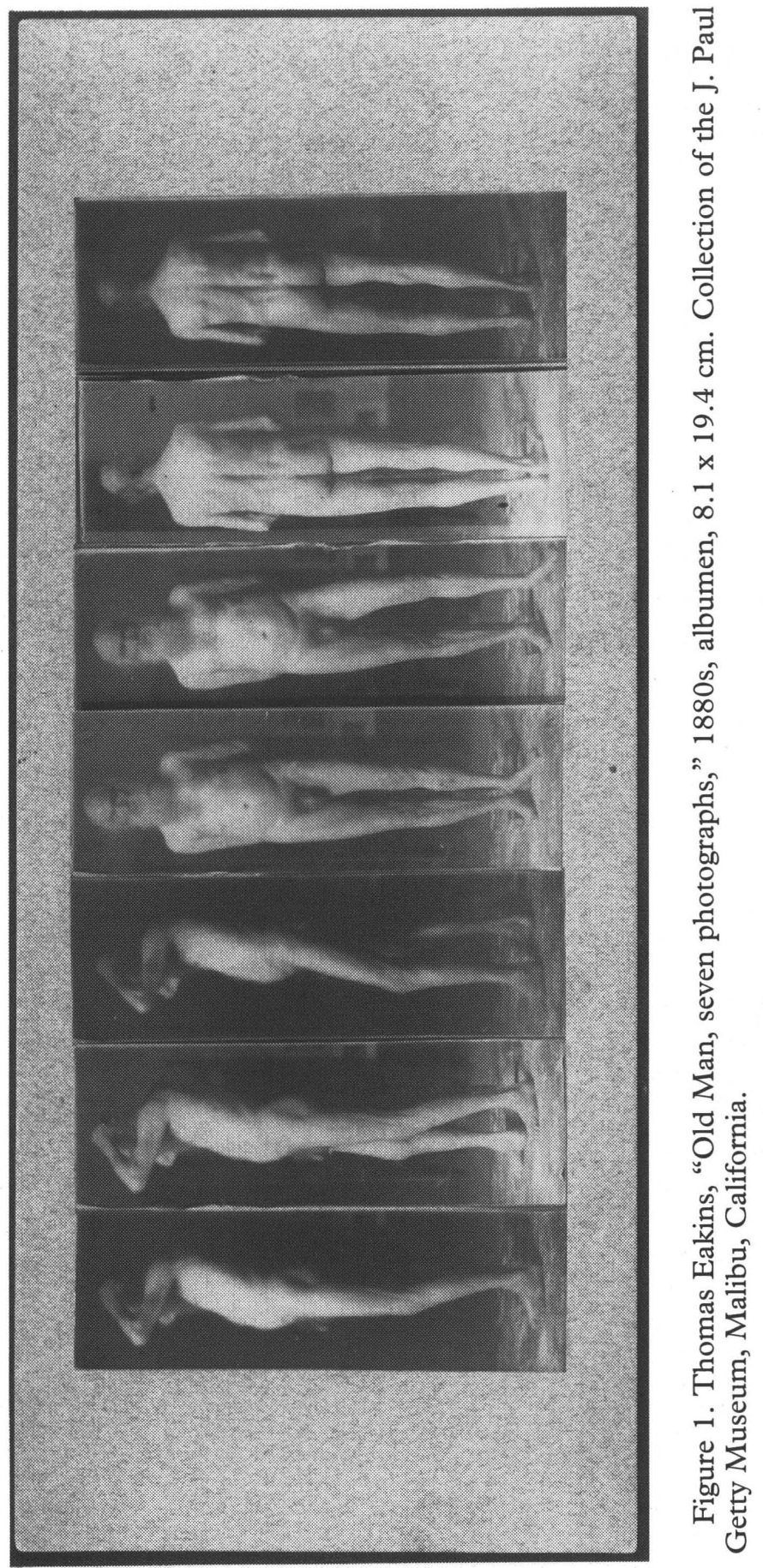


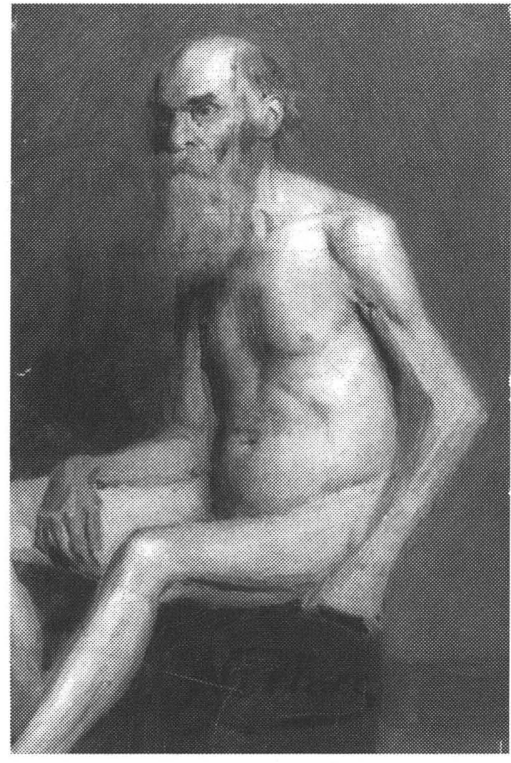

Figure 2. J. Laurie Wallace, "Old Man," oil on panel, ca. 1880, 7 " x 11". Joslyn Art Museum, Omaha, Nebraska. Gift of Mr. and Mrs. Joseph I. Baker in memory of George Barker.

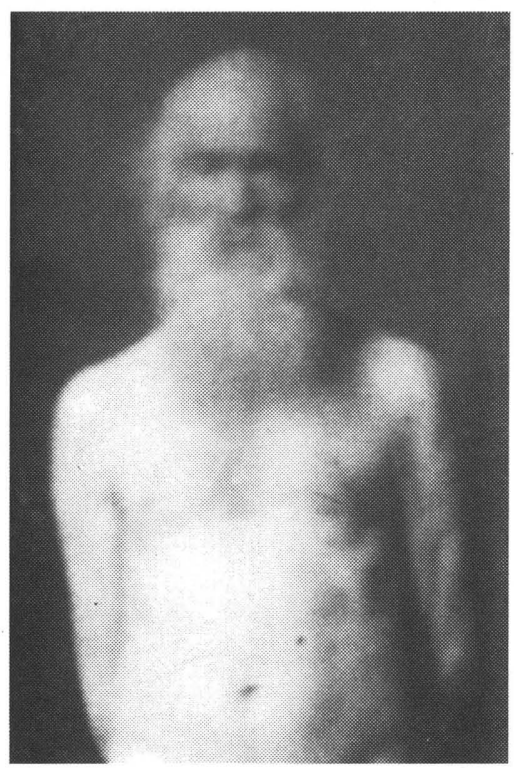

Figures 4 and 5: Thomas Eakins, "Old Man, seven photographs." Details. Collection of the J. Paul Getty Museum, Malibu, California. 